\title{
O Oriente Médio: a eventual cooperação brasileira para o estabelecimento da paz e as lições trazidas pela História
}

\section{NORMA BREDA DOS SANTOS}

Há algumas semanas ouvimos o presidente Fernando Henrique Cardoso anunciar que o governo brasileiro estaria disposto a enviar tropas ao Oriente Médio caso a ONU assim o decidisse, reafirmando a intenção do País de cooperar com a comunidade internacional para a implementação de ações objetivando a retomada do processo de paz entre palestinos e israelenses.

As palavras do presidente nos remetem a, pelo menos, duas questões importantes. A primeira tem a ver com a agora já antiga candidatura brasileira a um assento permanente no Conselho de Segurança da ONU. Nesse sentido, há motivos para saudar a recente atitude do governo brasileiro com relação ao conflito no Oriente Médio, menos tímida do que nos habituamos a ver nos últimos oito anos. Sem discutir aqui a viabilidade ou a validade de buscar-se um assento permanente no Conselho, o que é certo é que uma conduta de perfil baixo na cena internacional não se coaduna com a intenção brasileira de ocupar um espaço institucional tão importante.

A declaração do presidente também nos faz pensar na experiência histórica brasileira em operações militares no exterior e, particularmente, nos 10 anos de participação na primeira operação de manutenção da paz da ONU, instalada justamente no Oriente Médio (Sinai) em conseqüência da crise do Suez, de 1956, atuando exclusivamente no lado egípcio da fronteira entre Egito e Israel, uma vez que o governo israelense não reconheceu a validade jurídica da operação. Apesar dessa operação ter sido considerada bem-sucedida, documentos diplomáticos e militares apontam claramente pelo menos dois problemas sérios que a marcaram. De um lado, salta aos olhos o contato extremamente insuficiente entre o Itamaraty e o então Ministério da Guerra, responsável pelo preparo e envio do contingente brasileiro. De outro, a falta de qualquer planejamento objetivando aproveitar a experiência dos militares enviados ao Egito para promover a modernização e profissionalização do exército brasileiro.

Críticas a propósito da precária ou inexistente comunicação interministerial estão fartamente registradas em relatórios redigidos por oficiais militares que visitaram o contingente brasileiro no Sinai. Em um deles, afirmava-se, por exemplo, 
que, ainda que se acreditasse "que o Itamaraty tenha formulado alguma política ou elaborado algum estudo sobre a área, tais estudos jamais foram oficializados e encaminhados à execução para que todos os atos decorrentes fossem coerentes com as idéias e os princípios julgados oficialmente básicos. O Brasil não tem uma política geral para com as Nações Unidas, as forças de manutenção de paz, o Oriente Médio e a FENU”. De fato, não existia nenhum tipo de ação coordenada entre o Itamaraty e o Ministério da Guerra. Somente em maio de 1993 é que o Grupo de Trabalho Interministerial (GTI) foi estabelecido, sob a coordenação do Itamaraty, a fim de coordenar as ações empreendidas por diversos ministérios envolvidos em operações de paz.

Relatórios militares são igualmente eloqüentes sobre o segundo problema mencionado, ou seja, a falta de planejamento visando ao aperfeiçoamento dos militares brasileiros a partir da experiência internacional no Egito. Notavam os militares brasileiros que haviam estado no Sinai que a participação em operações de paz era aproveitada por vários países como uma escola para o aperfeiçoamento de seus quadros, o que contrastava completamente com a atitude das autoridades governamentais brasileiras. "Infelizmente, no Brasil”, observava um militar, “à experiência adquirida no exterior pouco valor é dado. Até hoje não são utilizados na preparação dos novos contingentes, oficiais e praças que já tenham estado na FENU. O Brasil poderia tirar grandes vantagens disso, mas nossos homens destacados para servir na FENU eram cabos e soldados que eram licenciados ao chegarem de volta ao Brasil. Os relatórios dos comandantes de batalhão apodrecem nas gavetas e nunca foram codificados ou transformados em experiência viva.”

Fica claro, portanto, que a ausência ou insuficiência de políticas coordenadas entre diversos setores governamentais tem longa data. Fica patente, ainda, que ações de tamanha importância, como o envio de contingentes militares ao exterior para participar de ações coletivas visando ao estabelecimento da paz ou sua manutenção, ainda que bem-vindas, têm que estar assentadas em uma política que faça eco, de maneira consistente, ao que se possa eleger como interesse nacional. Parece claro, por fim, que a história tem muito a nos ensinar. 